\title{
THE USE OF ARM SPAN AND KNEE HEIGHT FOR ESTIMATION OF STATURE AMONG NEPALESE MEDICAL STUDENTS
}

\author{
Niraj Pandey, ${ }^{1}$ Deepesh Budathoki, ${ }^{2}$ Gopal KC, ${ }^{2}$ Pradeep Chhetri ${ }^{3}$
}

\section{ABSTRACT}

\section{INTRODUCTION}

Height is a significant parameter for growth and development of an individual. Arm span and knee height measurement are useful when accurate measurement for stature is unobtainable. Studies have shown that the relationship between stature and arm span varies with age and population. Thus, the aim of the present study was to analyze the correlation between stature and two measurements; the arms span and knee height of medical students of Kathmandu Medical College Public Limited, Kathmandu, Nepal.

\section{MATERIAL AND METHODS}

This is a descriptive study. A total two hundred medical students, presently studying at Kathmandu Medical College, aged between eighteen and twenty eight years were randomly selected as the subjects for the present study. Among them, seventy six were females and one hundred twenty four were males. Arm span and knee height was measured by flexible steel tape and height was taken by stadiometer. The collected data were tabulated and SPSS 20 was used to perform analysis.

\section{RESULTS}

There is statistically strong correlation $(\mathrm{r})$ between height and arm $\operatorname{span}(\mathrm{r}=0.858,=0.736 ; \mathrm{r}=0.849,=0.720, \mathrm{p}<0.01$ for males and females respectively) while knee height too has shown a similar relationship $(\mathrm{r}=0.882,=0.778$, $\mathrm{r}=0.819,=0.670, \mathrm{p}<0.01$ for males and females respectively).

\section{CONCLUSION}

This present study revealed that both arm-span and knee height can be used in estimation of the height of both males and females. The regression equations so derived can be used in cadavers or an amputee or bed ridden patients with fairly accurate results. This can be helpful in medico- legal cases as well as in study of anthropology.

KEYWORDS arm span, knee height, anthropometry, stature

1. Department of Anatomy, Universal College of Medical Sciences, Bhairahawa, Nepal

2. Department of Anatomy, Kathmandu Medical College, Kathmandu, Nepal

3. Department of Community Medicine, Universal College of Medical Sciences, Bhairahawa, Nepal

DOI: https://doi.org/10.3126/jucms.v6i2.22471

\author{
For Correspondence \\ Dr. Niraj Pandey \\ Department of Anatomy \\ Universal College of Medical Sciences \\ Bhairahawa, Nepal \\ E.mail:drnp77@gmail.com
}




\section{INTRODUCTION}

Height is an important factor to assess nutritional status since accurate measurement of stature is very important in determining Body Mass Index (BMI), BMR, and for interpretation of lung function tests. ${ }^{1}$ However, measurement of stature in elderly people may not be measured perfectly due to kyphosis and scoliosis, non-ambulatory and critically ill patients. Arm span is the maximum distance between tips of the longest fingers of both hands while the person abducts both arms at the level of the shoulders at 90 degree angle. Knee height is defined as the length measured parallel to the long axis of the tibia from the heel of the foot to anterior surface of the thigh while ankle and knees are bent at a $90^{\circ}$ angle. ${ }^{2}$ It has an additional advantage as it could be measured while patient is seated or even lying down. ${ }^{3,4}$ Many studies have shown that all these anthropometric parameters are being influenced by genetic, environmental and biological factors. ${ }^{1,4,5}$ It has shown that a person's growth in height ceases at the chronological age of 19 years and after the age of 30 years onwards age related regressions occur. ${ }^{4,6,7}$ Thus, equations derived to predict stature using arm span and knee height is influenced by factors such as ethnicity age and gender. ${ }^{5}$ In the elderly people, it is appropriate to estimate stature from measurement of knee height and arm span.,

Inter and intra population variations may be observed in relation to anthropometry due to factors such as genetic makeup, age, gender and ethnicity. Though many Asian races have been studied in relation to these parameters, similar studies have not been done in Nepal. The aim of the present study is to analyze the correlation between stature and two anthropometric variables; the arm spans and knee height of students of Katmandu Medical College, Duwakot, Nepal.

\section{MATERIAL AND METHODS}

The study was carried out in the Kathmandu Medical College Duwakot, Kathmandu, Nepal. A total number of 200 students (males $=124$ and females $=76$ ) of $18-28$ years of age were studied. A fixed time 11 am to $4 \mathrm{pm}$ was selected for the physical measurement to eliminate the discrepancies due to diurnal variation. This is a descriptive study which was conducted throughout a period of three months from January to March 2017. Ethical clearance for the study was granted by the Ethical Review Committee of Kathmandu medical college public limited (Ref31082016).

Students were randomly selected and informed verbal consent was obtained. Students possessing skeletal deformities, physical disabilities, past history of skeletal injuries or diseases affecting bones and joints and students who cannot stand erect, who cannot bend their knee and who are on any form of hormonal medications were excluded. ${ }^{9}$ Arm span was measured with a flexible steel tape between the tips of both middle fingers of horizontally abducted and maximally outstretched hands and fingers with the subjects standing and facing the wall. Knee height is defined as the distance from the heel of the foot to the top of the patella, (most anterior surface of the femoral condyles of the thigh, medial being more anterior) with the ankle and knee each flexed to a $90^{\circ}$ angle measured by flexible steel tape. Standing height was measured using a stadiometer against the wall on barefoot with their heels together and the heels, buttocks and back touching the stadiometer.

All measurements were performed thrice and the mean value was obtained. The data was collected, tabulated and statistically analyzed by using SPSS version 20 . Simple linear Regression analysis in the form of equation $\mathrm{Y}=\mathrm{a}+\mathrm{bx}$, where $\mathrm{Y}$ is stature and arm span and knee height are independent variable $(\mathrm{X})$ and Pearson coefficients of correlation were calculated for stature and knee height and for stature and arm span. Prediction equations were then developed subsequently. ${ }^{9}$

\section{RESULTS}

A total of 200 students of Kathmandu Medical College (male $=124$, females $=76$ ) of 18-28 years of age were studied. There is statistically strong correlation ( $\mathrm{r}$ ) between height and arm span. $(\mathrm{r}=0.858,=0.736 ; \mathrm{r}=0.849,=0.720, \mathrm{p}<0.01$ for males and females respectively) while knee height too has shown a similar relationship $(\mathrm{r}=0.882,=0.778, \mathrm{r}=0.819,=0.670$, $\mathrm{p}<0.01$ for males and females respectively). Following equations were derived to predict the stature $(\mathrm{Y})$. In males, $\mathrm{Y}=46.678+0.711$ arm span, and $\mathrm{Y}=58.736+2.213$ knee height, in females $Y=46.678+0.711 \mathrm{arm}$ Span and $Y=59.109+$ 2.313 knee height. Stature, knee height and arm span measurements are shown in following tables 1,2 and 3 .

\section{Table 1. Physical measurement of all students}

\begin{tabular}{|l|l|l|l|}
\hline Variables & Mean & Standard deviation & Range \\
\hline Age $(\mathrm{yrs})$ & 20.6 & 1.4 & $(18-28)=10$ \\
\hline Stature $(\mathrm{cm})$ & 165.2 & 8.3 & $(146.5-184)=37.5$ \\
\hline Arm span $(\mathrm{cm})$ & 167.5 & 10.3 & $(142-192)=50$ \\
\hline Knee height $(\mathrm{cm})$ & 46.7 & 2.7 & $(39-59)=14$ \\
\hline
\end{tabular}

\section{Table 2. Physical measurement of male students}

\begin{tabular}{|l|l|l|l|}
\hline Variables & Mean & Standard deviation & Range \\
\hline Age $(\mathrm{yrs})$ & 20.9 & 1.4 & $(18-28)=10$ \\
\hline Stature $(\mathrm{cm})$ & 169.6 & 6.5 & $(152-184)=32$ \\
\hline Arm span $(\mathrm{cm})$ & 173 & 7.8 & $(149-192)=43$ \\
\hline Knee height $(\mathrm{cm})$ & 48 & 2.5 & $(53-41)=12$ \\
\hline
\end{tabular}




\section{Table 3. Physical measurements of female students}

\begin{tabular}{|l|l|l|l|}
\hline Variables & Mean & Standard deviation & Range \\
\hline Age $(\mathrm{yrs})$ & 20.0 & 1.3 & $(18-27)=9$ \\
\hline Stature $(\mathrm{cm})$ & 157.9 & 5.3 & $(172-146.5)=25.5$ \\
\hline Arm span $(\mathrm{cm})$ & 158.4 & 6.8 & $(173-142)=31$ \\
\hline Knee height $(\mathrm{cm})$ & 44.6 & 2 & $(49-39)=10$ \\
\hline
\end{tabular}

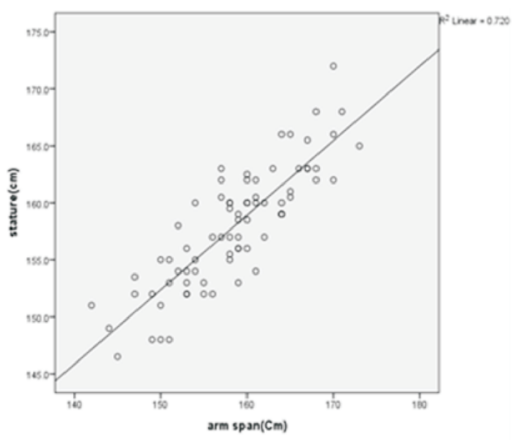

Figure 1. Scatter diagram and regression line showing relationship between arm span and stature of female

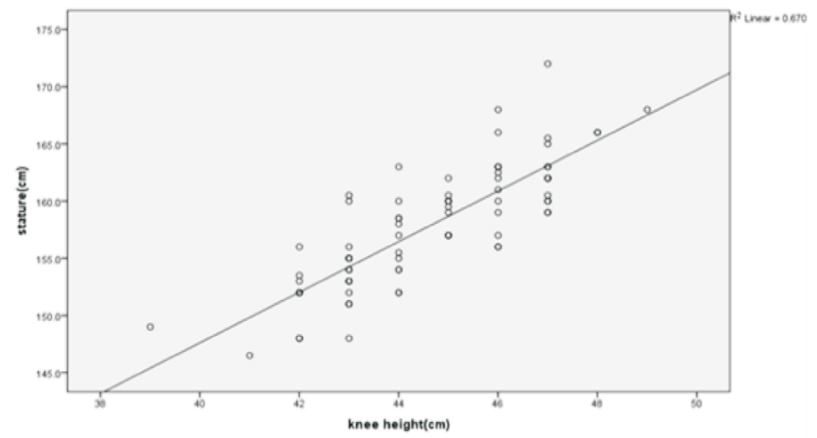

Figure 2. Scatter diagram and regression line showing relationship between Knee height and stature of female

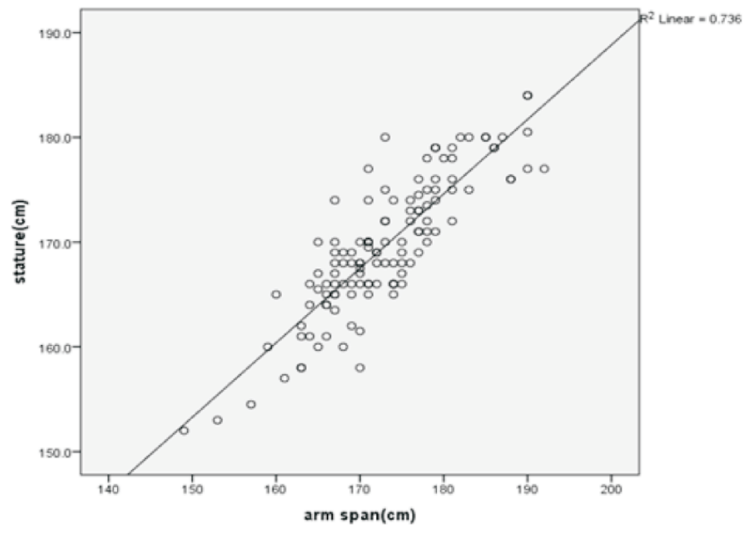

Figure 3. Scatter diagram and regression line showing relationship between arm span and stature of male

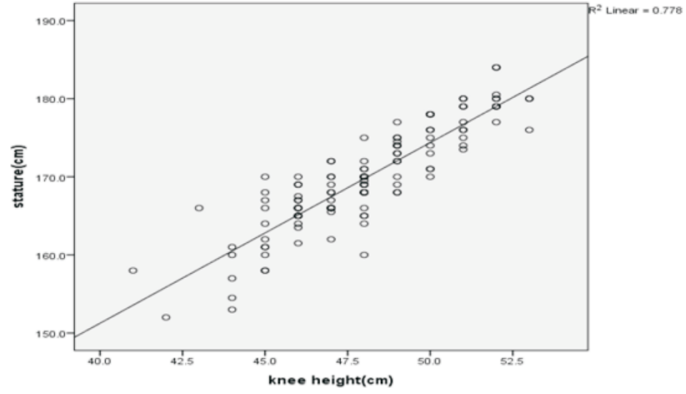

Figure 4. Scatter diagram and regression line showing relationship between knee height and stature of male

\section{DISCUSSION}

This study analyses the correlation coefficients of stature and arm span and then stature and knee height of the Nepalese medical students. Regression equations were derived to predict the stature. The study found that the males have higher anthropometric measurement than that of females in our study. Similar kinds of observations are made in other studies. ${ }^{1,8,10,11}$ These differences may be due to gender associated genetic factors, hormonal factors and lifestyle factors. ${ }^{1,8,10,11}$ In the present study, the difference in the arm span and height of the female group was $0.54 \mathrm{~cm}$, and a study by Mohanty et $\mathrm{al}^{4}$ where he studied a group of South Indian females of ages 20 to 26 years and obtained a difference of $2.5 \mathrm{~cm}$. Similarly, Steel and Chenier's ${ }^{12}$ study found $8.3 \mathrm{~cm}$ and $3.3 \mathrm{~cm}$ for black and white females respectively.

In the present study, knee height measurement has also shown a positive linear relationship with height $(\mathrm{r}=0.882,=0.778$, $\mathrm{r}=0.819,,=0.670, \mathrm{p}<0.01$ for males and females respectively) but Fatmah, ${ }^{8}$ Li et $\mathrm{al}^{11}$ and Shahar \& Pooy ${ }^{13}$ showed a better correlation between these parameters in their studies. It may be due to the variations in mean ages of above study groups, ethnicity of study groups and other environmental factors of growth. ${ }^{4,7}$ It is evident that the arm span can be used as the predictor of stature, but it should be borne in mind that ethnic specific equations should be derived for a specific ethnicity.,

After achieving maximum stature, the bones are in relatively static period up to 40 years of age then the natural process of senile degeneration takes place.

The present study has shown that the arm span is superior to knee height in predicting stature as the age group studied has not yet started age related regression and the mean age was 20.56 years. Similar findings were observed by Shahar \& $\operatorname{Pooy}^{13}(\mathrm{r}=0.81$ for males \& 0.84 for females) although the mean age of the study group was 42.3 years.

Our study showed significant strong positive linear 
relationships between arm span and stature and similar higher correlations were shown by Mohanty et $\mathrm{al}^{4}$, Shahar \& Pooy ${ }^{13}$ and Zverev \& $\mathrm{Chisi}^{14}$ too.

Regression equations derived to predict stature in Srilankan population are: Stature for males $(\mathrm{cm})=48.801+0.6784 \mathrm{AS}$ $(\mathrm{cm})$, stature for females $(\mathrm{cm})=47.451+0.678$ AS $(\mathrm{cm})$, stature for males $(\mathrm{cm})=73.945+1.784 \mathrm{KH}(\mathrm{cm})$, stature for females $(\mathrm{cm})=95.427+1.249 \mathrm{KH}(\mathrm{cm})^{9}$ and the regression equations for prediction of stature $(\mathrm{Y})$ in our study are: In males $Y=46.678+0.711$ arm span, and $Y=58.736+2.213$ knee height; in females $Y=46.678+0.711$ arm span and $Y=59.109+$ 2.313 knee height.

\section{CONCLUSION}

From the present study, it was concluded that arm span is the most reliable body parameter for predicting the height of an individual. The data obtained in the study may be useful as a reference in anthropologic, forensic and genetic research. Although, the sample size is not enough for representation of whole Nepalese population but it will serve as a basis of comparison for future studies in Nepalese population.

\section{ACKNOWLEDGEMENTS}

We are very grateful to the students of Kathmandu Medical College who participated in this study. We would like to thank Mr. Hari Sharan Makaju for assisting in data collection.

\section{REFRENCES}

1. Food and Nutrition Research Institute Philippines 1998, 'Arm Span and Knee height As Proxy Indicators for Height', 5th National Nutritional Survey, DOST, Mannilla

2. Kuchmarski RJ (1999) Need for body composition information in elderly subjects. Am. J. Clin. Nutr. 50: 1150-1157

3. Lohman TG, Roche AF. Anthropometric standardization reference manual. Martorell R, editor. Champaign: Human kinetics books; 1988.

4. Chumlea WC, Roche AF, Steinbaugh ML. Estimating stature from knee height for persons 60 to 90 years of age. Journal of the American Geriatrics Society. 1985 Feb 1; 33(2):116-20.

5. Mohanty SP, Babu SS, Nair NS. The use of arm span as a predictor of height: A study of South Indian women. Journal of Orthopaedic Surgery. 2001 Jun; 9(1):19-23.

6. Mendoza-Núnez VM, Sánchez-Rodríguez MA, CervantesSandoval A, Correa-Muñoz E, Vargas- Guadarrama LA. Equations for predicting height for elderly Mexican Americans are not applicable for elderly Mexicans. American Journal of Human Biology: The Official Journal of the Human Biology Association. 2002 May; 14(3):351-355.
7. KS Narayan Reddy. 'Identification', The Essentials of Forensic Medicine and Toxicology. 25th edition. K Suguna Devi; 2006, 50-86.

8. Fatmah F. Predictive equations for estimation of stature from knee height, arm span, and sitting height in Indonesian Javanese elderly people. Int J Med Med Sci. 2009; 1:456-61.

9. Varun R, Jayasinghearachchi TM, Priyalini R, Gunasena MD. Arm span and knee height as predictors of stature among Peradeniya medical students. Sri Lankan Journal of Anaesthesiology. 2012 Apr 6; 19(2):76-80.

10. Chumlea WC, Guo SS, Wholihan K, Cockram D, Kuczmarski RJ, Johnson CL. Stature prediction equations for elderly nonHispanic white, non-Hispanic black, and Mexican-American persons developed from NHANES III data. Journal of the American Dietetic Association. 1998 Feb 1; 98(2):137-142.

11. Li ET, Tang EK, Wong CY, Lui SS, Chan VY, Dai DL. Predicting stature from knee height in Chinese elderly subjects. Asia pacific Journal of clinical nutrition. 2000 Dec 29; 9 (4) : 252-255.

12. Steele MF, Chenier TC. Arm-span, height, and age in black and white women. Annals of human biology. 1990 Jan 1; 17 (6):533541.

13. Shahar S, Pooy NS. Predictive equations for estimation of stature in Malaysian elderly people. Asia Pacific journal of clinical nutrition. 2003 Mar 1; 12(1):80-84.

14. Zverev Y, Chisi J. Estimating height from arm span measurement in Malawian children. Collegium antropologicum 2005 Dec 15;29(2):469-73. 